\title{
Spinoza's Miracles: Scepticism, Dogmatism, and Critical Hermeneutics
}

\section{Introduction}

An old riddle, which was first formulated by Leo Strauss, ${ }^{1}$ has resurfaced in the last decade, capturing the imagination of several prominent scholars: ${ }^{2}$ is Spinoza's interpretation of miracles consistent with his literal sense hermeneutics? A review of the rhetoric used by several scholars when depicting this problem provides sufficient evidence in order to indicate the fundamentality of the philosophical beliefs that this puzzlement undermines. Thus, Warren Zev Harvey speaks about it in terms of 'enigmatic statements,' 3 stating that 'Spinoza is playing a game-but what?'4 Steven Nadler speaks about 'the perplexity generated by these anomalous passages, ${ }^{5}$ concluding his paper discussing the question in terms of mystery:

It is still a mystery why Spinoza believes, as he argues in chapter six, that as a matter of fact Scripture itself-or, rather, its prophetic authors-when properly interpreted does in fact ascribe natural causes to all events, even those it presents as miracles. ${ }^{6}$

Critical hermeneutics requires the reader to look for the meaning of prophecy and biblical teaching within only the biblical text. How can one derive the meaning of the biblical prophecy from the Bible itself? The first stage, according to Spinoza, is ach-

I am greatly thankful to the anonymous reader, Racheli Haliva, Zev Harvey, Ilil Hoz, Yitzhak Melamed, Amanda Parris, and Stephan Schmid, for their helpful comments.

1 Cf. Steven Nadler, "Scripture and Truth: A Problem in Spinoza's Tractatus Theologico-Politicus," Journal of the History of Ideas 74.4 (2013): 639, n. 40: 'For a long time, and as far as I could tell, only Leo Strauss took the incongruity of these passages with Spinoza's "whole principle of interpretation, that objective truth may not be used as the key for interpreting Scripture” seriously. But Strauss only concluded that all this shows is "how little Spinoza finds himself at ease in [his] critique of miracles.”"

2 Nadler, "Scripture and Truth: A Problem in Spinoza's Tractatus Theologico-Politicus," 623-642; Carlos Fraenkel, "Spinoza on Miracles and the Truth of the Bible," Journal of the History of Ideas 74.4 (2013): 643 - 658; Michah Gottlieb, "Spinoza’s Method(s) of Biblical Interpretation Reconsidered," Jewish Studies Quarterly 14 (2007): 286 -317; Warren Zev Harvey, "Spinoza on Biblical Miracles," Journal of the History of Ideas 74.4 (2013): 659-675.

3 Harvey, "Spinoza on Biblical Miracles," 659, 673 and 675.

4 Ibidem, 667 (my italics).

5 Nadler, "Scripture and Truth: A Problem in Spinoza’s Tractatus Theologico-Politicus," 623 (my italics).

6 Ibidem, 641-642 (my italics). 
ieved by using his literal sense method, i.e. deciphering the meaning of biblical prophecy requires us to study the prophetic statement taking its linguistic use as a starting point. If we know how a particular language was used at the specific time of the prophecy, we can reconstruct the its meaning. Spinoza posits his critical hermeneutics in stark contrast to dogmatic hermeneutics, which he defines as any interpretation which deciphers meaning according to the interpreter's own already established philosophical opinions rather than deriving it from the biblical text itself. ${ }^{7}$

Spinoza's hermeneutics is compatible with his separation thesis; theology and philosophy are two distinct domains that should not be conflated. Thus, a prophet's claim should not be explicated by means of a philosophical claim, and a philosophical claim should not be addressed in a theological manner. According to the separation thesis, regardless of whatever philosophical thesis the prophet holds (even an entirely false one), it does not imply that his prophecy contradicts or conflicts with the true philosophical view; the prophet's opinion is as little a part of the theological aspect of his prophecy as, for instance, the length of his hair; the only prophetic teaching is theological, and theological teaching has nothing to do with philosophical teaching.

Now, here is the question that puzzles scholars: when analysed philosophically, Spinoza argues, miracles are absurd and impossible; we would not have expected him to formulate it any differently. However, strangely enough, Spinoza claims that because miracles are impossible, we have to interpret the biblical miracles in such a way that the biblical text does not imply anything which is not in accordance with reason. Moreover, Spinoza claims that miracles are, in fact, a philosophical issue, and hence that we should explain the meaning of a prophetic statement in a way which would not result in a contradiction between the philosophical view of miracles and the prophet's view of miracles.

Hence, the riddle that Spinoza's reader is faced with is this: what reason could Spinoza have that would explain his deviation from critical hermeneutics, namely what reason could he have for applying dogmatic hermeneutics to the biblical miracles? Although the riddle focusses on miracles, Harvey claims, in a Straussian spirit, that Spinoza deliberately presented this contradiction in order to teach the reader how the TTP should be read as a whole. Harvey compares Spinoza's manner of composing a contradictory text to that of Maimonides in his Guide. Other scholars have offered other resolutions, ${ }^{8}$ but they all agree that 1 ) Spinoza's analysis of miracles is

7 I skip the important discussion concerning Spinoza's hermeneutics, as it is not essential for the purpose of this paper. For the sake of the main argument in this paper, I distinguish between literal sense method and critical hermeneutics as follows: literal sense method concerns the meaning of specific phrase or passage, whereas critical hermeneutics ascertains the prophetic/philosophic nature of the biblical expression or passage.

8 For an interesting discussion of the different approaches, see Harvey, "Spinoza on Biblical Miracles," 672ff.; Harvey names three types of resolution: the biographical (Strauss and Fraenkel), the harmonizing (Nadler), and the dialectical one (Harvey). 
dogmatic to some extent, and 2) the dogmatic interpretation of miracles stands in contrast to his critical hermeneutics, which requires us to study the prophet's view in light of the literal sense rule.

In contrast to this widely shared agreement, I would like to suggest an alternative interpretation which consists of the following theses:

1. Spinoza's analysis of miracles is, in fact, an expression of his anti-dogmatic commitments.

2. Spinoza's claim that the prophets were, in fact, committed to the same Spinozian view of miracles is the result of his critical hermeneutics.

3. Spinoza's analysis of miracles can contribute to an understanding of the biblical conception of miracles.

This alternative interpretation will help in resolving the puzzle. The order of presentation I will take in this paper will be:

1. The puzzle: Spinoza's analysis of miracles as a violation of his critical hermeneutics.

2. Miracles as a problem for Spinoza's hermeneutics.

3. Showing Spinoza's way out-Spinoza's hermeneutics actually informs our understanding of biblical miracles.

4. Claiming that Spinoza's analysis of miracles is, in fact, a clear expression of his commitment to anti-dogmatic hermeneutics.

\section{The Puzzle: Spinoza's Analysis of Miracles as a Violation of his Critical Hermeneutics}

For the sake of clarity, I will briefly present the link between Spinoza's separation thesis and his literal sense method. Then, I will present the puzzling deviation of Spinoza's analysis of miracles from his critical hermeneutics.

\section{Critical hermeneutics and the separation thesis}

Spinoza's critical hermeneutics can be crudely explained as consisting of two parts:

1. Application of the separation thesis-theology and philosophy are two distinct domains, distinguished in the following way:

I) Each has its own source of knowledge: the source of theological knowledge is prophetic revelation, whereas the source of philosophical knowledge is the natural light of reason.

II) Theology's medium for thinking the world is imagination, whereas philosophy's is reason.

III) The aim of philosophy is truth, whereas the aim of theology is obedience and piety. 
According to the separation thesis, the prophetic aspect of the Bible should consist of teachings in which the medium of thinking is imagination. The kind of teaching or knowledge that prophecy conveys has to do with piety and obedience. ${ }^{9}$

2. Literal sense method-the literal sense method enables the reader to separate the theological content of the prophet's expression from its philosophical content. Thus, the critical reader is not bothered by the truth or falsity of the prophet's expressions; the philosophical value of the prophet's opinion does not affect the theological value of prophetic expression, e.g., the prophet's view of God may be invalid philosophically, but entirely valid theologically.

\section{Miracles: a Deviation from Critical Hermeneutics}

I will now focus on two central discussions: the first is Nadler's discussion of Spinoza's deviation and the second is Harvey's discussion of Spinoza's apology. Let me just briefly elaborate on them.

\section{Nadler's Question: Spinoza's Dogmatic Deviation}

Nadler's discussion brings the reader directly to the heart of the problem. Summarising it, he says:

The issue is why Spinoza believes that Scripture's authentically prophetic authors cannot possibly assert anything about miracles that is "contrary to reason.'10

Let us now examine Spinoza's dogmatic thesis, the argument he provides to support it, and Nadler's question. Concerning the biblical view of miracles, Spinoza says:

If anything should be found [in scripture] which can be conclusively demonstrated to be contrary to the laws of nature, or to have been unable to follow from them, we must believe without reservation that it has been added to the Sacred Texts by sacrilegious men. For whatever is contrary to nature is contrary to reason; and what is contrary to reason is absurd, and therefore to be rejected. (TTP, 6 [51]; my italics)

Spinoza's conclusion here is that any passage found in the Bible which conveys the opinion that something happens which is 'contrary to the laws of nature' must be

9 I will skip the discussion as to how the mind's possession of revealed knowledge and the person's disposition to obey this knowledge are actually one and the same according to Spinoza. Spinoza does have an argument in store in favour of this equation, but it is beyond the scope of this paper. 10 Nadler, "Scripture and Truth: A Problem in Spinoza’s Tractatus Theologico-Politicus,” 639. 
considered a corrupt passage. He supports this claim by arguing that 'whatever is contrary to nature is contrary to reason; and what is contrary to reason is absurd.' Now, does the argument support the thesis? It seems that according to Spinoza's own objection to dogmatic interpretation, his argument does not support his conclusion, since the fact that from the perspective of reason nothing can be contrary to nature does not necessarily entail that the prophet cannot believe that this is exactly the case. Nadler puts this question very convincingly, saying:

Given everything that Spinoza has said about the nature of prophecy, the content of the prophetic writings, and the interpretation of Scripture, it is very surprising to see him say what he does in passage $\mathrm{C}^{11}$ In fact, it would seem to be precisely what he should not say, since it is inconsistent with his overall account of the interpretation of Scripture. His remarks in this passage are something that we might expect from Maimonides or Meijer, but not from Spinoza. According to Spinoza's considered account of Scripture, it is perfectly reasonable to expect the Bible's untutored authors to regard events as having supernatural causes and thus sincerely to narrate them in such a way that they 'contravene the laws of Nature,' or to possess an understanding of things that is 'contrary to reason' and, from reason's perspective, 'absurd'. But the prophets were not intellectually gifted individuals, much less Spinozist philosophers who identify God with Nature. Thus, there is no reason to expect, as a matter of principle, that the prophets believed that every event has a natural cause or can be explained through the laws of nature. Why, then, should it not at least be possible to find 'something in Scripture contrary to the light of Nature' without suspecting the piety of its author? As Spinoza himself says, in his objections to Maimonides's view that 'there is nothing in Scripture which contradicts reason,' 'I insist that Scripture expressly affirms and teaches that God is jealous [. . .] this is contrary to reason. ${ }^{, 12}$

Spinoza's thesis here is apparently a dogmatic one; however, his argument does not seem to support his thesis. Moreover, the reason for his deviation is quite puzzling: what could have been his reason for introducing such a dogmatic thesis that explicitly contradicts his own critical hermeneutics and possibly jeopardizes the aim of the TTP, namely the separation thesis?

\section{Harvey's Questioning of Spinoza's Apology}

In a passage that Harvey describes as Spinoza's apology, Spinoza explicitly addresses our question. Yet Harvey claims that instead of offering an answer, Spinoza's apology only expands the question. According to Harvey, Spinoza's apology is so puzzling that we must assume that Spinoza was playing a game which needs to be explained in a different way. Let us follow Spinoza's apology and Harvey's question. Spinoza's apology reads:

11 Referring to the passage I have just quoted above.

12 Nadler, "Scripture and Truth: A Problem in Spinoza's Tractatus Theologico-Politicus,” 637. 
Before I end this chapter, there's something else I want to note. I've proceeded regarding miracles according to a method completely different from the one I followed regarding Prophecy. Concerning Prophecy I affirmed nothing but what I could infer from foundations revealed in the Sacred Texts. But here I've elicited the main points only from principles known to the natural light. I did this deliberately. For since Prophecy surpasses man's power of understanding, and is a purely Theological question, I could affirm nothing about it, nor even know in what it chiefly consisted, except from the foundations which have been revealed. I was compelled to put together a history of Prophecy, and to formulate certain doctrines from it, which would teach me the nature and properties of Prophecy, as far as this can be done. [66] But concerning miracles what we are asking is completely philosophical: can we grant that something happens in nature contrary to its laws, or something which couldn't follow from them? So I didn't need anything like that. (TTP, 6 [65-6])

Spinoza is thus completely aware that in his analysis of miracles, he deviates from the critical hermeneutics which he used for the analysis of prophecy. Harvey boldly questions Spinoza's distinction between miracles and prophecy, saying:

\begin{abstract}
The apologia begins with Spinoza's admission that he has treated the subject of biblical miracles completely differently from that of biblical prophecy. He explains that in discussing prophecy in chapter one he had based himself on 'foundations revealed in Sacred Writ,' for prophecy is a 'purely theological' subject, but in discussing miracles he has based himself on 'foundations known by means of the lumen naturale,' for the subject of miracles is 'plainly philosophical.' The petitio principii here is so flagrant that it must be supposed to be intentional.

Spinoza is playing a game-but what? One would have thought that the subjects of prophecy and miracles are for Spinoza very similar. Prophecy may be understood as being rational and natural (e.g., the natural knowledge of the intelligent individual) or imaginary and supernatural (e.g., the visions of the biblical prophets which are said to be 'beyond the limits' of natural knowledge and inexplicable by 'the laws of human nature'); and so too miracles may be understood as being rational and natural (e.g., the extra light at Gibeon was caused by the hail) or imaginary and supernatural (e.g., the light was caused by the sun's standing still in the heavens). Spinoza claims that the subject of prophecy is 'theological' because it 'surpasses human knowledge' (captum humanum superat), whereas that of miracles is 'philosophical' because it involves the philosophical question of 'whether we can concede that something may happen in Nature that contravenes its Laws.' However, he might just as easily have said: the subject of prophecy is 'philosophical,' for it involves the philosophical question of whether there can be suprarational knowledge, whereas that of miracles is 'theological, ${ }^{13}$
\end{abstract}

Harvey's puzzlement assumes that Spinoza's critical hermeneutics provides no reason to explicate miracles and prophecy differently; if what is at stake is the difference between natural light and supernatural light (reason or imagination), then both prophecy and miracles can be addressed either philosophically or theologically. Spinoza's claim that miracles are the object of philosophy whereas prophecy is the object of theology is as arbitrary as it gets.

I think we are now in a position to summarise the different aspects of the main problem, which is Spinoza's inconsistency: despite his strong commitment to his own 
critical hermeneutics, his analysis of miracles is committed to dogmatic hermeneutics. More specifically, there are two issues:

1. That the prophet's understanding of miracles is compatible with the philosophical one. Thus, in cases where we cannot explain a biblical paragraph concerning miracles in a philosophical way, we have to censor this paragraph.

2. Spinoza's distinction between miracles and prophecy on the basis of reason and the prophetic kind of cognition does not make any sense.

\section{Miracles as a Problem for Spinoza's Hermeneutics}

In this part, I will suggest the following thesis: a miracle-when interpreted according to Spinoza's literal sense method-is apparently a significant problem for Spinoza's critical hermeneutics, if we suppose that the latter assumes that the literal sense method and the separation thesis are compatible.

In his apology, Spinoza states: 'I affirmed nothing but what I could infer from foundations revealed in the Sacred Texts' (TTP, 6 [65]). It might be helpful to review the last paragraph of chapter 2, in which Spinoza summarises the thesis he infers from his analysis of prophecy:

Although only the things we have said about the Prophets and Prophecy pertain particularly to my purpose of separating Philosophy from Theology, nevertheless, because I have treated Prophecy generally, I want to ask now whether the gift of Prophecy was peculiar to the Hebrews or whether it was common to all nations. We also need to ask what we must maintain about the calling of the Hebrews. That's the object of the following chapter. (TTP, 2 [58])

Spinoza's claim is quite explicit: the literal sense analysis of prophecy is intended to support the separation thesis. Now, how does it achieve this? Spinoza briefly explains the separation thesis in the preface:

Having shown the fundamentals of faith [in chapter 14], I conclude finally that revealed knowledge has no object but obedience, and indeed that it is entirely distinct from natural knowledge, both in its object and in its foundation and means. Revealed knowledge has nothing in common with natural knowledge, but each is in charge of its own domain, without any conflict with the other. [In chapter 15 I show that] neither ought to be the handmaid of the other. (TTP, preface [27]; my italics)

The separation thesis, then, stipulates that the distinction between revealed knowledge and natural knowledge (theology and philosophy) is clear-cut: these are two completely distinct domains of knowledge which have 'nothing in common' with each other and cannot conflict. The first two chapters on prophecy and the prophet are rich in content. However, according to Spinoza's claim, all of the discussions concerning prophecy were designed to support his separation thesis. How do they support it? Skipping a detailed analysis, I will point out two kinds of discussions which do so: 
1. The analysis of prophecy shows that the foundations of revealed knowledge are different from the foundations of natural knowledge. Thus, since revealed knowledge is knowledge of the imagination, one should not take the prophet's philosophical opinions to have any theological validity. For instance, regarding the revelation to Cain, Spinoza says:

For example, the revelation to Cain [Genesis 4:6-7] teaches us only that God warned him to lead a true life, for that was the only intent and substance of the revelation, not teach the freedom of the will or Philosophic matters. So even though the freedom of the will is contained very clearly in the words and reasonings of that warning, we are permitted to think the will is not free, since those words and reasonings were only accommodated to Cain's power of understanding. (TTP, 2 [53]; my italics)

2. Critical hermeneutics can disclose the meaning in which revealed knowledge is a domain in and of itself. Thus, for instance, by disclosing the manner in which a revelation is validated, we see that revealed knowledge does not appeal to reason.

One of Spinoza's main discussions revolves around the source of certainty. Literal sense hermeneutics, he argues, helps us to decipher the inner criteria for certainty with regards to revealed knowledge. Spinoza concludes the first chapter with the following telling passage:

As a result, we're now forced to ask how the Prophets could have come to be certain of things they perceived only through the imagination, and not from certain principles of the mind. But whatever we can say about this, we must seek from Scripture. As we have already said, we do not have true 'knowledge of this matter, or we cannot explain it through its first causes. What Scripture teaches concerning the certainty of the Prophets, I shall show in the following chapter, where I have decided to treat of the Prophets. (TTP, 1 [48])

Certainty, according to Spinoza, accompanies any piece of knowledge which is deduced by reason. [See TTP, 2 [4-6]] There is no need for any further act of the mind in order to become certain of the truth of any piece of knowledge which is derived by reason. In contrast, knowledge achieved by imagination requires an additional element in order to be endowed with certainty.

It is important to note here that Spinoza's comment-'we're now forced to ask how the Prophets could have come to be certain of things they perceived only through the imagination, and not from certain principles of the mind' (TTP, 1 [48]) -turns out to be very telling. Why are we forced to ask this when the certainty is coming from the imagination, but not when it comes from the principles of the mind? If we were to derive this certainty from our principles of reason, then the separation thesis could not be as strong as Spinoza claimed it was, namely we could not claim that 'revealed knowledge has nothing in common with natural knowledge, but each is in charge of its own domain, without any conflict with the other' (TTP, preface [27]). Thus, being committed to the strong version of the separation thesis, Spinoza has to reject the premise that prophecy obtains its certainty from certain 
principles of the mind. To summarize: Spinoza's strong separation thesis is intimately linked with his view that the certainty of prophecy cannot originate in reason.

Yet to come to our point now: Spinoza claims that in order to determine the source of certainty when it comes to revealed knowledge, we must read the Bible using his method.

\section{Certainty and Revealed Knowledge}

In the last section, we showed the significance of Spinoza's hermeneutics to his separation thesis. Moreover, we have seen that Spinoza is committed to the strong version of the separation thesis, namely that revealed knowledge should not be supported by means of reason. According to Spinoza, it is part of the task of chapter 2 to show that the certainty which accompanies revealed knowledge is not being informed through reason. If we fail to make this distinction, we will not be able to abide by the strong version of the separation thesis.

So, what is it indeed that endows revealed knowledge with certainty?

But first I must treat the certainty of the Prophets, both because it concerns the theme of this chapter, but also because it will help in some measure to get to the conclusion we intend to demonstrate. [4] Unlike a clear and distinct idea, a simple imagination does not, by its nature, involve certainty. So to be able to be certain of things we imagine, we must add something to the imagination-viz., reasoning. It follows that, by itself, Prophecy cannot involve certainty. As we've shown, it depended only on the imagination. So the Prophets were not certain about God's revelation by the revelation itself, but by some sign. (TTP, 2 [3-4])

The certainty which accompanies revealed knowledge is not revelation, but a sign. After giving different examples from the Bible, Spinoza concludes:

This shows that the Prophets always had some sign by which they became certain of the things they imagined Prophetically. That's why Moses warns [the Jews] to seek a sign from [anyone claiming to be] a Prophet, viz. the outcome of some future event (Deuteronomy 18:22). [6] In this respect, then, Prophecy is inferior to natural knowledge, which needs no sign, but of its own nature involves certainty. (TTP, 2 [5-6])

Indeed, the certainty which accompanies revealed knowledge is inferior to the certainty which accompanies natural knowledge. Yet Spinoza has successfully shown that this certainty does not come from reason. The certainty to which the prophet aspires is achieved through a sign which is as imaginary as prophecy itself.

To summarise: according to our explication, the only way we can account for the certainty of revealed knowledge without violating the strong version of the separation thesis is by pointing our the exact role of the sign plays in endowing certainty to prophetic knowledge; we can understand the role of the sign only by closely critically studying the biblical text. 


\title{
Signs and Miracles
}

But what is the kind of sign that endow prophetic revelations with certainty according to Spinoza? Interestingly enough, at least in certain cases, Spinoza identifies miracles as signs. For instance, in chapter 2, it reads:

Indeed, this Prophetic certainty was not mathematical, but only moral, as is evident from Scripture itself. For in Deuteronomy 13[:2] Moses warns that any Prophet who wants to teach new Gods should be condemned to death, even though he confirms his teaching with signs and miracles. For as Moses himself goes on to say, God also uses signs and miracles to test the people. $(T T P, 2[7])^{14}$

Moreover, later in the chapter Spinoza says:

\begin{abstract}
Similarly, the sign of the backward motion of the shadow was revealed to Isaiah according to his power of understanding, viz. as a backward motion of the sun [cf. 2 Kings 20:8-12 with Isaiah 38:7-8]. For he too thought that the sun moves and that the earth is at rest. As luck would have it, he never thought of parhelia, not even in a dream. We are permitted to maintain this without any hesitation because the sign could really happen, and be predicted to the king by Isaiah, even though the Prophet did not know its true cause. (TTP, 2 [28])
\end{abstract}

Spinoza notes that having to explicate 'the backward motion of the sun' in terms of imagination does not necessarily mean that it could not be explained by reason. However, in chapter 6 , Spinoza refers to the same event, saying:

We ought not doubt that many things are related as miracles in the Sacred Texts whose causes can easily be explained according to known principles of natural things. We already hinted at this in Ch. 2 when we spoke about the sun's standing still in the time of Joshua, and its going backward in the time of Ahaz. But we'll soon treat this more fully, when we discuss the interpretation of miracles, as I've promised to do in this chapter. (TTP, 6 [15])

Here, Spinoza discusses the same event, but in terms of miracle. So, if miracles can be a sign, I suggest we turn now to discuss the place of miracles in revealed knowledge.

14 Cf. TTP, 6 [31]: 'For he says that (even if) a sign and a wonder he has predicted to you should happen, etc., do not (nevertheless) assent to the words of this Prophet etc., because the Lord your God tests you etc. (Therefore) let that Prophet be condemned to death etc. From this it clearly follows that even false Prophets can perform miracles, and that unless men are well protected by the true knowledge and love of God, miracles can lead them to embrace false Gods as easily as the True God. For Moses adds since the Lord your God is testing you, to know whether you love him with all your heart and all your soul.' 


\section{Miracles as Signs: the First Problem}

A miracle can serve as a sign, but what is a miracle? I think we are now in a position to see the difficulties that miracles create in Spinoza's dual commitment, namely to both literal sense hermeneutics and his separation thesis.

If we return to the scholars previously discussed, I think we can say that a miracle is an event perceived by both the Bible and the prophet as violating the law of nature. Now, if we say that a sign is a miracle, how does it contribute to theology? To answer this question, we would have to explore how a miracle can endow the prophet's revelation (or his audience) with certainty that the sign is indeed a miracle. A miracle shows that providence can violate the natural order; providence's interference with the natural order is a sign that adds certainty to the content of revelations.

If we are correct in our interpretation of Spinoza as being committed to a strong version of the separation thesis, which requires (as we have suggested) a revelation to be explained without any reference to reason, then a miracle qua sign will not be very helpful. After all, the prophet's entire conviction is based on an argument of reason which roughly claims: you have seen an event, and you know that events generally follow the natural law, the laws of reason. However, what you have seen here is a miracle, which means that providence can bend the laws of nature; this is a sign telling you that prophetic revelation is true. If we accept this explication of miracle and sign, we see that miracles-when interpreted according to the literal sense methodpresent a serious difficulty to Spinoza: this kind of certainty would be explicitly informed by an argument from reason.

However, there is one good reason to reject my interpretation, because by adopting dogmatic hermeneutics, Spinoza falls down yet another pit. Let me elaborate: if we accept Spinoza's position on miracles, then the Bible and the prophet agree with him and miracles are not events which are bent by providence to violate laws of nature. So, what is the contribution of non-existent miracles to prophetic certainty? Let me suggest a revised version of this refuted interpretation of mine.

\section{The Sceptic and the Dogmatic}

Spinoza posits his critical hermeneutics in opposition to two hermeneutical schools. We have already discussed the opposition to dogmatic hermeneutics. In chapter 15 , Spinoza posits critical hermeneutics against sceptical hermeneutics.

Spinoza depicts the sceptic's reading of the Bible in the following way:

Those who don't know how to separate Philosophy from Theology debate whether Scripture should be the handmaid of reason, or reason should be the handmaid of Scripture-that is, whether the meaning of Scripture ought to be accommodated to reason, or reason ought to be accommodated to Scripture. The skeptics, who deny the certainty of reason, defend the accommodation of reason to Scripture. (TTP, 15 [1]) 
Spinoza is aware of the fact that the sceptic is following literal sense method to a certain extent. In chapter 15, he makes the following comment on the sceptic:

Insofar as he wants to explain Scripture by Scripture, I praise him. But I'm amazed that a man endowed with reason should be so eager to destroy reason. It's certainly true that Scripture ought to be explained by Scripture, so long as we're only working out the meaning of the statements and the Prophets' intention. (TTP, 15 [8])

Before I turn to discuss Spinoza's objection to the sceptic, let me just point out that Spinoza's adversary in his discussion of miracles is very likely a sceptic. Spinoza describes the common people as those who have the tendency to claim that miracles are God's actions that violate the natural order (TTP, 6 [2-5]). Spinoza explains the motivation driving them in the following manner:

So the common people call unusual works of nature miracles, or works of God. Partly from devotion, partly from a desire to oppose those who cultivate the natural sciences, they don't want to know the natural causes of things. They long to hear only the things they're most ignorant of, which they're most amazed by. (TTP, 6 [3])

The desire to 'oppose those who cultivate the natural sciences' is quite similar to the depiction of the sceptic's madness in chapter 15:

Who but someone desperate and mad would want to recklessly say goodbye to reason, or to scorn the arts and sciences, and deny the certainty of reason? (TTP, 15 [38])

In fact, the sceptic's resemblance to the miracle advocate comes up in a context that is more significant to our discussion. In chapter 15 , Spinoza says:

Who but someone desperate and mad would want to recklessly say goodbye to reason, or to scorn the arts and sciences, and deny the certainty of reason? [...] They want to call upon reason to repudiate reason, and by a certain reason make reason uncertain. While they're trying to show the truth and authority of Theology by mathematical demonstrations, and to take away the authority of reason and the natural light, all they're doing is dragging Theology under the control of reason. They clearly seem to suppose that Theology has no brilliance unless it's illuminated by the natural light. (TTP, 15 [38-9])

The sceptic in chapter 15 is actually the one who 'calls upon reason to repudiate reason.' If we return to Spinoza's miracle adversary, we see that he meets the sceptic's criteria. In chapter 6, Spinoza depicts the miracle advocate:

Next, we know that nothing agrees with nature (or is contrary to it) except what we have shown to agree with those principles (or to be contrary to them). So if we could conceive that by some power (whatever in the end it was) something could happen in nature which was contrary to nature, that would be contrary to those first notions, and we would have to reject it as absurd-either that, or we would have to doubt the first notions (as we have just shown) and consequently, doubt God and all things, however they might have been perceived. (TTP, 6 [18]) 
Thus, Spinoza states here that anyone who claims that miracles are events that violate the laws of nature (i.e. the miracle advocate) is actually claiming that reason refutes reason (i.e. the sceptic). We see, then, that according to Spinoza, when someone claims that miracles are contrary to the natural order, what he is saying is actually a statement about knowledge.

\section{Critical Hermeneutics and the Sceptic's Argument from Miracles}

Is Spinoza's thesis regarding the compatibility between literal sense hermeneutics and the separation thesis in danger, if Spinoza's miracle adversary is indeed the sceptic? As Spinoza grants, the sceptic's approach is quite similar to his own when it comes to the literal sense interpretation. (TTP, 15 [8]) So, let us reconstruct the sceptic's argument and review Spinoza's answer.

Let us first a compare Spinoza's answer to the sceptic concerning prophecy with his answer concerning miracles. In the case of prophecy, the sceptic's argument would be the following: the literal sense implies that prophecy is true, and since prophetic knowledge is different from natural knowledge, accepting prophetic truth implies that natural knowledge is subordinate to natural knowledge. Spinoza's answer to this is that critical hermeneutics indeed confirms that prophetic knowledge is valid. However, it also confirms that revealed knowledge is made valid by imagination; hence it does not imply anything concerning reason. As long as we can keep the domains of theology and philosophy separate, namely as long as they do not inform each other, then there is no basis for the sceptic's position, just as there is no basis for the dogmatic one.

What is the case for miracles? The sceptic's argument would be that the certainty of the revelation is endowed by the sign or the miracle. If we go back to Spinoza's claim that a miracle is an action on the part of providence against the order of nature-which is tantamount to the claim that reason refutes reason-then the biblical teaching supports scepticism.

Can Spinoza refute the sceptic's argument by arguing from the separation thesis? In contrast to the case of prophecy, in the case of miracles, the answer seems to be no. It seems to be the case that theological knowledge is informed by reason, and since certainty of revealed knowledge is dependent on the insight that knowledge of reason is invalid, the separation thesis cannot hold.

Now we can return to our original difficulties: does Spinoza have a reason to adopt dogmatic hermeneutics in his interpretation of miracles? The answer is yes; if he does not adopt this kind of hermeneutics, the literal sense method is in support of the sceptic.

- Does Spinoza have a reason to claim that the prophets hold the same views as he does concerning miracles? Yes: if theology admits that miracles imply an interruption of the natural order, then the separation thesis is disproved (remember that in 
order to refute the separation thesis, we only need to show that theology is not supported by its own means).

- Does Spinoza have a good reason to distinguish between miracles and prophecy, stating that the question of miracles is philosophical, whereas the question of prophecy is a purely theological? Yes: prophetic knowledge can be entirely explained as proceeding from the foundations of theology, hence investigating its teaching in accordance with the literal sense method makes sense; however, since miracles cannot explain theology without relying on natural knowledge, they cannot qualify as revealed knowledge.

- Does Spinoza have a good reason to suggest applying censorship in case the Bible implies that miracles support theology? Yes, otherwise we would have to agree with the sceptic that biblical teaching is dependent on knowledge of reason.

\section{Should We Accept that Spinoza's Analysis of Miracles is a Dogmatic One?}

Our interpretation challenges the scholars' claim that Spinoza had no good reason to adopt a dogmatic hermeneutics in his interpretation of miracles. In contrast, our interpretation shows that he had very good reasons for adopting dogmatic hermeneutics. Contrary to the scholars' claim that the reason for adopting a dogmatic hermeneutics has nothing to do with Spinoza's own hermeneutics, we have seen that Spinoza's reason for doing so was his own literal sense method.

As appealing as our interpretation may be for explaining Spinoza's reason for his deviation from the literal sense method, it remains very weak: what kind of answer would that be on Spinoza's part? Merely claiming that the literal sense method should not be used in that particular case just because it violates another thesis is an interpretation which could perhaps sound convincing to certain historians of philosophy, but would Spinoza qua philosopher also be convinced?

If we wish to interpret Spinoza qua philosopher, we have to address the following two challenges to our interpretation:

1. Can Spinoza's explication of biblical miracles be supported from his critical hermeneutics?

2. Does Spinoza have an answer to the sceptic's challenge from miracles which does not suspend the literal sense method when it comes to miracles?

\section{Spinoza's Explication of Miracles Reconsidered}

Up until now, we have accepted the scholars' premise that Spinoza's interpretation of miracles is indeed a dogmatic one. Yet our interpretation, which identifies Spinoza's miracle adversary as the sceptic, can serve as the pivotal point for turning our perception of Spinoza's view of miracles upside down. I will argue that using our inter- 
pretation, we can show that Spinoza's analysis of miracles does not necessitate the suspension of the literal sense method; rather, Spinoza has a good answer to the sceptic which keeps the literal sense method in effect.

The philosophical challenge that Spinoza faces is how to show that a miracle can support the certainty of revealed knowledge from its own domain. Another question is: how can miracles support theology if we do not assume that they violate the natural order?

\section{Miracles and Certainty of Revealed Knowledge}

Philosophically speaking, our interpretation of Spinoza will be more solid if we show that miracles can be signs which endow prophetic knowledge with certainty. Now, even if we accept the common reading, namely that Spinoza's interpretation of miracles is a dogmatic one, we still have to explain how miracles qua signs create certainty in the prophet's (or the believer's) mind.

Now, even if we do accept this view, we should keep in mind Spinoza's firm theses that 1) the prophets themselves believed that miracles were not an interruption to the natural order, and 2) biblical teaching or theology agrees with philosophy in rejecting miracles (assuming that the meaning of the latter is an action of providence which interrupts the natural order). Yet what could a miracle be, if we reject the latter understanding of miracles? Can a miracle have any theological meaning (in terms of imagination) which would not imply a violation of the natural order?

Spinoza suggests a certain mental affect caused by miracles. In chapter 1 , the text reads:

That's also why they called miracles works of God, i.e., works to be astonished at. For of course, all natural things are God's works, and exist and act only through the divine power. It's in this sense that the Psalmist calls the miracles of Egypt God's powers, because in a situation of extreme danger they opened up the way to deliverance for the Hebrews, who were expecting nothing like them, and hence were amazed by them. (TTP, 1 [30])

Thus, astonishment or amazement are affects that can be triggered by miracles. Yet the fact that a miracle causes astonishment and amazement does not bring us much further: it is possible that the effect of amazement is actually the result of reasoning that providence is interfering with the natural order. But if we can show that miracles can be understood to support theology without having to depend on reason, our interpretation will not violate the separation principle.

In fact, Spinoza explicitly claims that when we refer to 'amazement', we are not in violation of the separation principle. In chapter 6 , he says:

Though the voice the Israelites heard [on Mount Sinai] could not give them any philosophical or mathematical certainty about God's existence, still, it was enough to make them wonder at God, insofar as they had previously known him, and to motivate them to obedience. That was the pur- 
pose of that manifestation. God did not want to teach the Israelites the absolute attributes of his essence. (He did not reveal any of them at that time.) He wanted to break their stubborn heart and win them over to obedience. So he addressed them with the sound of trumpets, with thunder, and with lightning, not with arguments. (TTP, 14 [36]; my italics)

Spinoza's argument here gives us several clues which could be helpful in our analysis of miracles. He begins by noting that we should not assume that arguments play any role in the way in which miracles are related to revealed knowledge. In accordance with the latter claim, Spinoza is using 'amazement' to mean 'that which connects the imaginary mind to revealed knowledge.' In addition, Spinoza explains the role of miracles on Mount Sinai in the following way: the people already knew God, namely miracles were in no way supposed to convey the knowledge of God. However, the fact that they already knew that God existed did not make them ready to accept the knowledge revealed on Mount Sinai or to follow it; the miracles on Mount Sinai, then, were supposed to connect the people to the revealed knowledge. ${ }^{15}$

To recapitulate what we have just unpacked from chapter 6: we can keep the domains of philosophy and theology entirely distinct if we understand miracles only in terms of imagination (the affect of wondering). Miracles connect a person's mind to the content of the revelation by the affect of amazement (imagination).

Now, let us see how the aforementioned insight can help us to understand the prophet's certainty in revealed knowledge. Certainty, or the prophet's readiness to commit himself to the knowledge revealed to him, is achieved through the amazement which accompanies the miracle.

We still have to account for two points:

1. What is it about the affect of amazement which accompanies miracles that connects the beholder to revealed knowledge?

2. Can we account for the role of miracles in achieving certainty when the prophet conceives a miracle as merely a natural event (as we explained with reference to Nadler, Spinoza states that the prophets agreed with him that miracles are natural events).

\section{Is the Mind Capable of Perceiving an Event as Both Natural and Miraculous?}

Spinoza claims that miracles are events which cause us to be amazed, yet the prophet can wonder at the event and simultaneously hold the view that it is entirely natural. However, is this not an empty formula? Can we really wonder at an event, see it as a sign, and the same time perceive it as being entirely natural?

15 Spinoza's preference for the term 'sign' over 'miracle' will also get clearer by our interpretation. 
In fact, I would argue that Spinoza is referring to a very common state of mind. Think of the following two examples. In the first case, I win the lottery, I feel really fortunate, and I say: 'God really loves me. I am blessed.' Now consider the second case, which conveys an opposite view of myself: I am an academic and all my efforts over many years to obtain a professorship at the university have been futile. I am unemployed and I say: 'I am so unlucky, God really hates me, I am cursed.' Can I not think, in the first case, both that my winning the lottery may be explained by the laws of causality which govern the lottery machine and yet at the same time feel that I am lucky, that I am blessed, and that God loves me? Consider now the second case: can I not admit that the reason I did not obtain a professorship is because-in accordance with the natural order-only those who are endowed with professorial wisdom obtain this position, and I am not one of them? And can I not think at the same time that I am unlucky, unfortunate, and cursed by God?

Let us now apply that state of mind to the prophet: knowledge is revealed to the prophet through imagination, but he still lacks certainty. He then wins the lottery; he sees it as a sign that God is in direct contact with him, that God is interested in him, that God loves him, that he is very special to God, etc. If this is the prophet's state of mind, it is possible for him to consider the event as both something which does not violate the natural order and yet as a sign that God has a special relationship with him.

\section{Re-examination of Spinoza's Dogmatism}

Let us now proceed to re-examine Spinoza's analysis of miracles in chapter 6 in light of our interpretation. Spinoza's theses-1) that the prophets consider miracles to be natural events and 2) that the Bible must teach that miracles are natural events-are defendable if Spinoza is committed to the strong version of the separation thesis; accordingly, the contribution of miracles qua signs to the certainty of revealed knowledge can be accounted for only from the realm of imagination. Thus, if we account for the certainty of prophecy by assuming that a miraculous event provides evidence for the superiority of revealed knowledge over natural knowledge, we violate the separation thesis.

The aforementioned theses are in perfect accordance with Spinoza's literal sense method. As we have seen, at the end of chapter 2, Spinoza claims that his analysis of prophecy in chapters 1 and 2 supports the separation thesis. We therefore concluded that the separation thesis is derived from the biblical text in accordance with the literal sense method. ${ }^{16}$ For that very reason, the certainty of the sign must be accounted

16 This claim does not entail that a derivation of the separation thesis from reason is excluded according to Spinoza; our claim here is only the following: the separation thesis can be derived-and Spinoza does in fact derive it-from theological principles, independently of its derivation from reason, and vice versa. 
for from theological theses only. We have shown that Spinoza indeed accounts for the certainty a sign lends to revealed knowledge exclusively from the principles derived from prophetic revelation.

In his apology, Spinoza states that miracles are the object of philosophy alone and that therefore they should be addressed with reason alone. We reviewed two difficulties:

1. Nadler's objection:-is that thesis not a violation of Spinoza's literal sense method?

2. Harvey raised the following difficulty:

Spinoza claims that the subject of prophecy is 'theological' because it 'surpasses human knowledge' (captum humanum superat), whereas that of miracles is 'philosophical' because it involves the philosophical question of 'whether we can concede that something may happen in Nature that contravenes its Laws.' However, he might just as easily have said: the subject of prophecy is 'philosophical', for it involves the philosophical question of whether there can be suprarational knowledge, whereas that of miracles is 'theological'. ${ }^{17}$

A careful examination of Spinoza's apology in light of our interpretation resolves both Nadler's and Harvey's questions. It is worthwhile to quote Spinoza's apology once again:

I've proceeded regarding miracles according to a method completely different from the one I followed regarding Prophecy. Concerning Prophecy I affirmed nothing but what I could infer from foundations revealed in the Sacred Texts. But here I've elicited the main points only from principles known to the natural light. I did this deliberately. For since Prophecy surpasses man's power of understanding, and is a purely Theological question, I could affirm nothing about it, nor even know in what it chiefly consisted, except from the foundations which have been revealed. I was compelled to put together a history of Prophecy, and to formulate certain doctrines from it, which would teach me the nature and properties of Prophecy, as far as this can be done. [66] But concerning miracles what we are asking is completely philosophical: can we grant that something happens in nature contrary to its laws, or something which couldn't follow from them? So I didn't need anything like that. Indeed, I thought it wiser to unravel this question according to foundations known to the natural light, as those which are most known. I say that I thought it wiser, for I could easily have resolved it solely from the doctrines and foundations of Scripture. (TTP, 6 [65-6])

We have shown that 1) Spinoza's claim that a miracle is the result of providence's interruption of the law of nature is actually the sceptical claim that natural knowledge is inferior and should therefore be corrected by revealed knowledge. We have also claimed that 2) the sceptic's argument is to use reason to counter reason. Now, in the apology, Spinoza says: 'But concerning miracles what we are asking is completely philosophical: can we grant that something happens in nature contrary to its laws, or something which couldn't follow from them?' (TTP, 6[66]; my italics). Thus, the thesis

17 Harvey, “Spinoza on Biblical Miracles,” 666-667. 
of Spinoza's adversary regarding the 'interruption of the natural order' would indeed be the sceptic's thesis. As we have shown, the sceptic's thesis is one that is derived from reason, and hence Spinoza is entirely justified in claiming that such an understanding of miracles-'that something happens in nature contrary to its laws'should in fact be approached and answered from reason. This is precisely what Spinoza is doing when he examines the theses which are apparently derived from this understanding of miracles.

Our interpretation ultimately resolves both Nadler's and Harvey's objections: Spinoza does not violate the literal sense method, but rather refutes the sceptic's theses with philosophical arguments, and this approach is in fact the proper one, because the sceptic's understanding of miracles is derived 'from reason.' This would also explain why he says that in this respect, the issue of miracles is a philosophical matter, whereas the issue of prophecy is a theological one.

The interpretations we have reviewed and rejected consider Spinoza's stance on miracles to be a dogmatic one. I think we have explained our objections. As a matter of fact, our interpretation yields an interesting result: Spinoza's explication of miracles in chapter 6 is anti-dogmatic. His argument against the sceptic shows that the sceptic's explication of miracles only makes sense if we assume that 'something happens in nature contrary to its laws,' but in Spinoza's terms, this would be a philosophical claim. Thus, the sceptic is, in fact, the one who is committed to dogmatic hermeneutics. This might seem like a purely formal claim, but I think that our interpretation proves that this is exactly the case in terms of actual biblical interpretation. The sceptic's dogmatic understanding of miracles actually imposes an anachronistic interpretation of the Bible. In other words, by adopting the dogmatic view that miracles are 'something that happens in nature contrary to its laws,' the sceptic subjects the Bible to a philosophical problematic which is mostly a medieval one; from the critical point of view there is no reason to attribute such a view to the prophets. Conversely, we have shown that Spinoza's claim that the prophets are in agreement with the view that miracles are not an interruption of the natural order is what ultimately liberated him from the view that miracles should be regarded as biblical teaching. Once free from this view, we are able to grasp the difference between prophecy and miracles; only then is it possible to examine the role miracles play in the Bible, to understand the difference between signs and revealed knowledge, etc. 
